\title{
INTRAREGIONAL DIVERSIFICATION OF THE LEVEL OF THE FINANCIAL SITUATION OF THE POVIATS OF EASTERN POLAND IN RELATION TO THE DEVELOPMENT POTENTIAL
}

\author{
Paweł Dziekański' ${ }^{1}$ Andrzej Pawlik²
}

\begin{abstract}
Territorial self-government is an independent entity that has a certain scope of freedom in deciding on the path of development of the subordinate area, common property, and implementation of public tasks. The aim of the study is to assess the intra-regional diagnosis of the level of the poviat's financial situation relative to the development potential. The data used to conduct the study refer to the years of 2009 and 2016; they come from the Local Data Bank and cover 101 poviats of Eastern Poland. The poviat can carry out its tasks when it is equipped with stable and efficient sources of income. The level and structure of budget revenues determine investment activity. The socio-economic space of the poviat's activity is a multi-element system. It achieves different levels of development depending on the structure, equipment elements, as well as the quality and complexity of the links between them. The ability of a poviat to operate can be seen as a set of factors that are mutually related to each other. These factors include: technical infrastructure, knowledge, innovation, regional product, eco-development, geographical location, finances. These factors depend on the potential inherent in the region, activity in the sphere of planning and implementation of regional policy by regional self-government authorities, the state's economic policy, and the standards of structural policy and EU cohesion policy. These factors are not unchangeable over time; therefore, they should be subjected to continuous and ongoing analysis. The synthetic measure of the financial situation according to the average value of the 2007-2016 years was in the range from 0.24 to 0.49 . Poviats with a higher rate of the synthetic financial situation are better in terms of the measure of development. The level of the indicator is influenced by: the economic character of the entity and the function of the area, economic potential, financial situation, quality of the natural environment and infrastructure. The management of financial resources is of special importance in the functioning of poviats. They affect the economic situation of the local government, the conditions for the implementation of tasks. Financial resources are the basis for the operation of individuals and a condition for the implementation of the tasks imposed on them, they determine development and are an expression of the potential for economic development. The situation of the surveyed units varied. The ranking of cities in the ranking did not change substantially in the subsequent years. It was confirmed that financial resources are the basis for the operation of individuals and a condition for carrying out the tasks imposed on them, determine development, and reflect the potential for economic development.
\end{abstract}

Key words: financial situation, development, Eastern Poland, poviat, synthetic measure.

JEL Classification: C38, H71, H76, B41, R10, P25

\section{Introduction}

Territorial self-government is an independent entity that has a certain scope of freedom in deciding on the path of development of the subordinate area, common property, and implementation of public tasks. Its local resources (economic, financial, social, as well as information resources) determine the level of development. Therefore, the effective operation requires proper shaping of resources and rules of operation and then setting goals and ways to achieve them. This is difficult due to limited access to detailed, homogeneous information for all surveyed units (Dziekański, 2018; Dziekański, 2018a).

Diversified development of individual regions is a natural problem of each country. Geographical and natural conditions mean that individual regions are characterized by a different economic situation and level of development (Marcysiak, Prus, 2017). We should strive to make the most of the economic potential of the regions and improve their competitiveness. This is to safeguard the regions against the process of marginalization. Their effects in the territorial systems are polarization and 
divergence processes. They can lead to depopulation and degradation of some areas (Michoń, 2017).

According to Gorzelak (2003), regional diversification deepens and becomes excessive due to the instability of regional systems and cumulative processes. In the light of Myrdal's cumulative causality theory, regional systems appear as long-term structures, in which developed regions (centres) maintain the previously achieved advantage, and the development of less developed regions is inhibited by the effects of leaching (Domański, 2010). Spatial diversity of resources in the process of specialization and division of labour causes economic and social inequalities in regions.

It is worth emphasizing that analyses carried out by Churski and co-authors (2013) and Stanny (2013), Dziekański (2018) show that the most important development factor, next to the location in the socioeconomic space, are the local finances. The financial situation includes not only the financial position but also the ability of the local government to continue providing services and repaying liabilities, both the longand short-term (Governmental Accounting Standards Board). The financial situation is shaped, among others by: income level, financial independence, investment expenditure, ability to raise extra-budgetary resources, the financial result (Ossowska and Ziemińska, 2010). Other conditions may be shaped by, for example, the location and size of local government units (LGs), available resources and natural assets, investment attractiveness, economic fluctuations in the country and around the world, the condition of public finances, scope of income and expenditure authority (Dziekański, 2014; Dziekański, 2016).

Poviat as an intermediate level realizes tasks related to the following areas: education, healthcare, social assistance, tourism and collective transport, environmental protection and water management (Olejniczak-Szałowska, 2000). The scope and quality of public goods and services provided, increasing the investment attractiveness of the local government depend largely on the income, both own and foreign, and the ability to use them effectively, which in practice translates into the financial situation of the unit (Bieniasz et al., 2013).

\section{The aim, method, and research material}

The aim of the study is to assess the recognition of intra-regional differentiation of the poviat's financial situation with respect to development potential.

The analysis was made on the basis of a synthetic measure and selected diagnostic variables of 101 poviats of Eastern Poland. The data used to conduct the study relate to the years 2009 and 2016 and come from the Local Data Bank. A set of variables included a description of, among others, financial situation, economic potential, demographic and infrastructure potential, as well as income from PIT and CIT, own, property expenses. The choice of variables was guided by the substantive usefulness in the assessment of the studied phenomenon and the degree of variability and correlation of variables (Kukuła, 2014; Kukuła, 2000; Malina, 2004) ${ }^{1}$.

In the case of taxonomic methods, it is important to determine the nature of variables describing the studied phenomenon. Depending on the influence of stimulants and destimulants on the studied phenomenon, which were subjected to the standardization procedure using the zero uniformization method according to the formula (1) and (2), i.e.:

$$
\begin{aligned}
& z_{i j}=\frac{\mathrm{x}_{i j}-\min _{i} \mathrm{x}_{i j}}{\max _{i} \mathrm{x}_{i j}-\min _{i} x_{i j}} \text {, if } x_{i} \in S \\
& z_{i j}=\frac{\max _{i} \mathrm{x}_{i j}-\mathrm{x}_{i j}}{\max _{i} \mathrm{x}_{i j}-\min _{i} \mathrm{x}_{i j}} \text {, if } x_{i} \in D
\end{aligned}
$$

where: $\mathrm{S}$ - stimulant, D - destimulant; $\mathrm{i}=1,2, \ldots \mathrm{N}$; $j=1,2, \ldots, p$ ( $N$ is the number of objects (municipalities), and $\mathrm{p}$ - the number of features); $\mathrm{x}_{\mathrm{ij}}$ - means the value of the jth characteristic for the given unit, max - the maximum value of the jth feature, min - the minimal value of the jth feature (Wysocki, Lira, 2005).

The synthetic measure of development and financial situation was determined using the TOPSIS method. The calculated measures are included in the area (0.1), which ensures the comparability of results. The value of the synthetic measure for individual examined objects was determined on the basis of formula (3):

$$
q_{i}=\frac{d_{i}^{-}}{d_{i}^{-}+d_{i}^{+}} \text {, where } 0 \leq q_{i} \leq 1, i=1,2, \ldots, n \text {; }
$$

where: $d_{i}^{-}-$means the distance from the anti-clock, $d_{i}^{+}$- distance from the pattern (Wysocki, 2010, 156157). A higher value of the indicator (closeness of the tense) means a more favourable situation of the object, a lower (near zero) lower value (Zalewski, 2012; Łuczak, Wysocki, 2012).

The studied area of the poviats of Eastern Poland was finally divided into 4 quartile groups. The size of the indicator in the first group means the better unit, the last one being the weakest. The cross-compliance of the results obtained was also verified based on the correlation coefficient. A scatter plot with a fit line and regression analysis is also presented (Dziekański, Wyszkowski, 2018; Wysocki, Lira, 2005).

\section{Development and financial situation}

The poviat can carry out its tasks when it is equipped with stable and efficient sources of income. The level and structure of budget revenues determine investment activity. The socio-economic space of the poviat's activity is a multi-element system. It achieves different levels of development depending on the structure, equipment

\footnotetext{
${ }^{1}$ Variables characterized by low spatial variability (coefficient of variation below 0.10 ) and high correlating variables were removed from the further research process.
} 
elements, as well as the quality and complexity of the links between them.

Local development is a complex phenomenon, which results from many factors that shape it. The pressure on constant local development and provision of high-quality public services with simultaneous multidirectional activities means that the financial resources are far from sufficient (Hok, 2016). The functioning and development of territorial self-government depend on social, economic, and environmental factors. They determine the spatial diversification of social and economic development of territorial communities (Prus, Drzazdzyńska, 2017). At the same time, they are generated both by the needs of the local community and the level of local resources (Satoła, Standar, Kozera, 2019).

The financial situation is an element of the local authorities' responsibility for the development of the individual and meeting the needs of its residents. The assessment of the financial situation allows determining the efficiency of these units' functioning, the ability to meet their obligations, and the possibility of increasing the quality standard of services provided to local communities (Dziekański, 2014). As Cabaleiro-Casal et al. (2013) note, the financial situation cannot be described by means of one-dimensional space (one indicator). The value of the financial situation measure can be used as a tool to investigate how various factors affect it, how the implemented financial policy looks. The financial situation is a complex phenomenon. It is shaped by income, financial independence, the size of investment expenditures, the ability to raise extrabudgetary resources, and financial results (Ossowska, Ziemińska, 2010). The limited financial resources in relation to the scope of ongoing tasks and reported investment needs are one of the basic problems of the functioning of local self-government (Gonet, 2013).

The financial situation is shaped both by financial variables and by a number of conditions related to a given area. External determinants include the level of unemployment, the inflation rate, the social and economic situation of neighbouring areas. In turn, the internal conditions of the financial situation may be shaped by local authorities (e.g. through the use of disability pensions, activation of human resources, increasing management efficiency) (Ślusarz, 2005).

\section{Spatial differentiation of the financial situation of the counties of Eastern Poland}

Eastern Poland is an area comprising five voivodships: Lubelskie, Podkarpackie, Podlaskie, Świętokrzyskie, and Warmińsko-Mazurskie. It constitutes the area with the lowest level of economic development in Poland. Problems adversely affecting the economic situation and development prospects to a large extent have a structural dimension resulting from historical conditions. They are reinforced by the effects of peripheral location on the external border of the European Union, low innovation and infrastructural problems and the labour market (Operational Program Eastern Poland).

The lower efficiency of work in Eastern Poland is the effect of the poorer supply of voivodships with regional assets, such as infrastructure, technological and innovative potential, as well as infrastructure. Eastern Poland is characterized by a distinct specificity in the field of industry's industrial structure (Development Strategy of Eastern Poland, 2020).

The synthetic measure of the financial situation according to the average value of years 2009 and 2016 was in the range of 0.24 (poviat gołdapski - WarmińskoMazurskie Voivodeship; kazimierski - Świętokrzyskie; hrubieszowski - Lubelskie) to 0.49 (poviat białostocki Podlaskie). Poviats of Eastern Poland were divided into four quartile groups. The best and weakest units in groups are presented in Table 1. Poviats with a higher degree of the synthetic financial situation are at the same time better in terms of the measure of development. The obtained measures indicate spatial disproportions in the examined aspect.

The level of the indicator is influenced by: the economic character of the unit and the function of the area (industrial, tourist, residential), economic potential, financial situation, quality of the natural environment and infrastructure (attractiveness of the location, rent of location). Among the non-natural factors, the most important are: the neighbourhood of cities, as well as proximity to transport hubs (GłowickaWołoszyn, Satoła, 2018).

The existence of areas with a low level of the financial situation between territorial units means a loss of development potential. Intraregional diversification is shown in Table 2. The weakest unit in terms of the financial situation in 2009 turned out to be the kazimierski poviat (0.20, Świętokrzyskie Voivodeship, a poviat with a strong agricultural function), the best unit was the staszowski poviat $(0.51$, Świętokrzyskie Voivodeship; Industrial). In 2016, the best unit was the białostocki poviat (0.60, Podlaskie Voivodeship), the poorest poviat units: gołdapski (WarmińskoMazurskie, 0.27) and hrubieszowski (Lubelskie, 027). In the analysed years, the average value of the financial situation measure was the best in group I, which had 22 and 24 units. The smallest group was IV.

The analysis of the measure of development contained in Table 3 indicates the spatial disproportions of poviats of Eastern Poland. The group A poviats were in the best situation (average value of 0.39 (23 units in 2009) and 0.41 ( 24 units in 2016)), the weakest - in group D, respectively 0.27 (20) and 0.29 (22). In 2009, the poorest units were poviats: janowski, zamojski (Lubelskie) moniecki (Podlaskie) - 0,25, najlepszymi stalowowolski (Podkarpackie) ostrowiecki (Świętokrzyskie) - 0,44, in 2016, respectively hrubieszowski, krasnostawski (Lubelskie) - 0,27 and mielecki (Podkarpackie) - 0,48. 
Table 1

The synthetic measure of the financial situation of counties of Eastern Poland in 2009 and 2016

\begin{tabular}{|c|c|c|c|c|c|c|}
\hline \multirow{2}{*}{ Group } & & \multicolumn{2}{|c|}{$\begin{array}{c}\text { Measure } \\
\text { financial situation }\end{array}$} & \multirow{2}{*}{$\begin{array}{l}\text { The average value } \\
\text { of the financial } \\
\text { situation measure } \\
(2007-2016)\end{array}$} & \multicolumn{2}{|c|}{$\begin{array}{c}\text { Measure } \\
\text { synthetic development }\end{array}$} \\
\hline & & 2009 & 2016 & & 2009 & 2016 \\
\hline \multirow{2}{*}{ I } & białostocki (B) & 0,48 & 0,6 & 0,49 & 0,39 & 0,43 \\
\hline & ostrowiecki (T) & 0,40 & 0,40 & 0,37 & 0,44 & 0,41 \\
\hline \multirow{2}{*}{ II } & ropczycko-sędziszowski (R) & 0,34 & 0,41 & 0,36 & 0,32 & 0,36 \\
\hline & tarnobrzeski(R) & 0,30 & 0,40 & 0,33 & 0,32 & 0,36 \\
\hline \multirow{2}{*}{ III } & włodawski (L) & 0,28 & 0,36 & 0,32 & 0,28 & 0,28 \\
\hline & ostródzki (N) & 0,31 & 0,35 & 0,30 & 0,40 & 0,44 \\
\hline \multirow{4}{*}{ IV } & leżajski (R) & 0,29 & 0,32 & 0,29 & 0,32 & 0,33 \\
\hline & hrubieszowski (L) & 0,21 & 0,27 & 0,24 & 0,27 & 0,27 \\
\hline & kazimierski $(\mathrm{T})$ & 0,20 & 0,30 & 0,24 & 0,27 & 0,31 \\
\hline & gołdapski $(\mathrm{N})$ & 0,23 & 0,27 & 0,24 & 0,33 & 0,33 \\
\hline
\end{tabular}

Sorted by average measure value; The best and the weakest unit in the group I - very good, II - good, III - poor, IV - bad; Voivodeship: B - Podlaskie, T - Świętokrzyskie; R - Podkarpackie; L - Lubelskie; N - Warmińsko-Mazurskie

Source: own study based on data of BDL, GUS 2009, 2016

Table 2

A number of territorial units assigned according to the measure of synthetic financial situation to quarterly groups in 2009 and 2016

\begin{tabular}{|c|c|c|c|c|c|c|c|c|c|}
\hline & & \multicolumn{4}{|c|}{2009} & \multicolumn{4}{|c|}{2016} \\
\hline & & I & II & III & IV & I & II & III & IV \\
\hline Lubelskie & 20 & 2 & 3 & 8 & 7 & 7 & 5 & 5 & 3 \\
\hline Podkarpackie & 21 & 5 & 7 & 7 & 2 & 7 & 4 & 6 & 4 \\
\hline Podlaskie & 14 & 4 & 7 & 3 & 0 & 3 & 4 & 4 & 3 \\
\hline Świętokrzyskie & 13 & 6 & 3 & 1 & 3 & 3 & 4 & 4 & 2 \\
\hline Warmińsko-Mazurskie & 19 & 5 & 3 & 6 & 5 & 4 & 8 & 3 & 4 \\
\hline number of units & & 22 & 23 & 25 & 17 & 24 & 25 & 22 & 16 \\
\hline average & & 0,40 & 0,34 & 0,30 & 0,25 & 0,45 & 0,39 & 0,35 & 0,31 \\
\hline $\min$ & & \multicolumn{4}{|c|}{ kazimierski (T) 0,20 } & \multicolumn{4}{|c|}{ hrubieszowski (L) gołdapski (N) 0,27 } \\
\hline $\max$ & & \multicolumn{4}{|c|}{ staszowski $(\mathrm{T})$ 0,51 } & \multicolumn{4}{|c|}{ białostocki (B) 0,60} \\
\hline
\end{tabular}

B - Podlaskie, T - Świętokrzyskie; R - Podkarpackie; L - Lubelskie; N - Warmińsko-Mazurskie

Source: own study based on CSO BDL data

Table 3

A number of territorial units assigned according to development measure to quarterly groups in 2009 and 2016

\begin{tabular}{|c|c|c|c|c|c|c|c|c|c|}
\hline & & \multicolumn{4}{|c|}{2009} & \multicolumn{4}{|c|}{2016} \\
\hline & & I & II & III & IV & I & II & III & IV \\
\hline Lubelskie & 20 & 3 & 3 & 4 & 10 & 3 & 3 & 4 & 8 \\
\hline Podkarpackie & 21 & 8 & 6 & 3 & 4 & 10 & 7 & 1 & 3 \\
\hline Podlaskie & 14 & 1 & 3 & 5 & 5 & 1 & 3 & 4 & 6 \\
\hline Świętokrzyskie & 13 & 5 & 3 & 4 & 1 & 5 & 3 & 4 & 1 \\
\hline Warmińsko-Mazurskie & 19 & 6 & 6 & 7 & 0 & 5 & 7 & 3 & 4 \\
\hline number of units & & 23 & 21 & 23 & 20 & 24 & 23 & 18 & 22 \\
\hline average & & 0,39 & 0,33 & 0,3 & 0,27 & 0,41 & 0,35 & 0,31 & 0,29 \\
\hline $\min$ & & \multicolumn{4}{|c|}{ janowski, zamojski (L) moniecki (B) 0,25} & \multicolumn{4}{|c|}{ hrubieszowski, krasnostawski (L) 0,27 } \\
\hline $\max$ & & \multicolumn{4}{|c|}{ stalowowolski (R) ostrowiecki (T) 0,44 } & \multicolumn{4}{|c|}{ Mielecki (R) 0,48 } \\
\hline
\end{tabular}

B - Podlaskie, T - Świętokrzyskie; R - Podkarpackie; L - Lubelskie; N - Warmińsko-Mazurskie

Source: own study based on CSO BDL data 

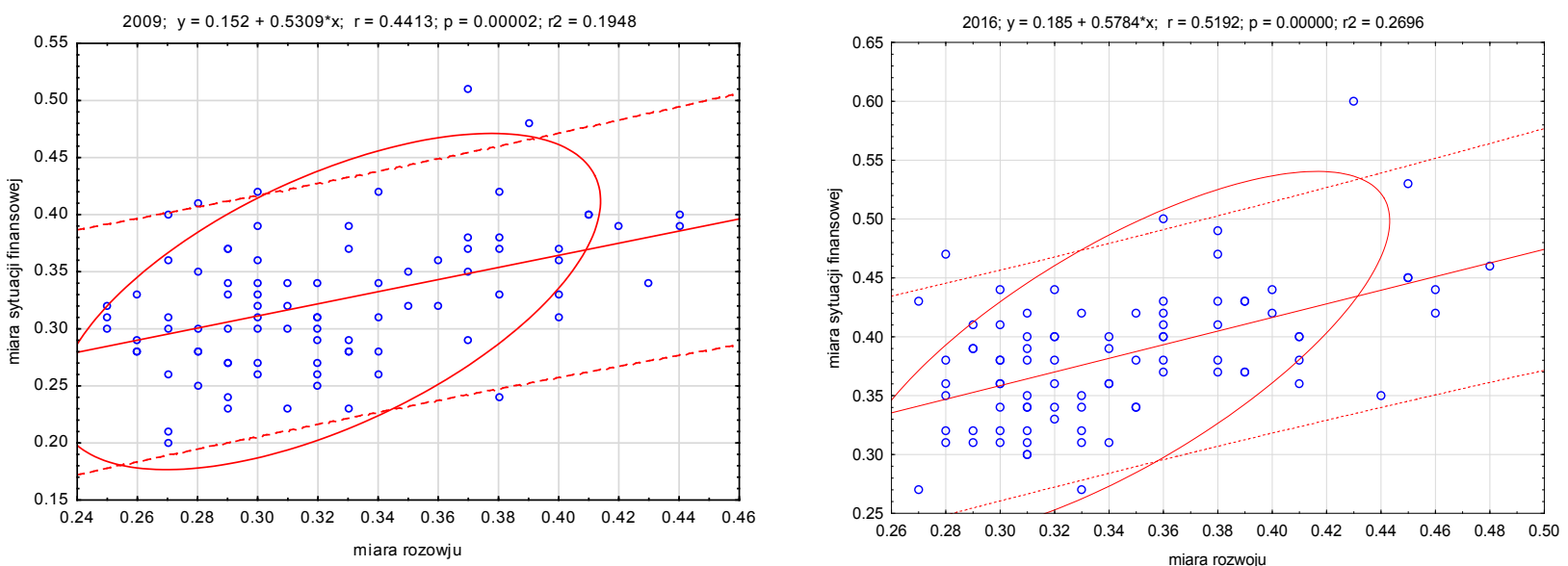

Figure 1. The regression graph with the line matching the relationship between the measure of synaptic finance and development in 2009 and 2016

Source: own study based on CSO BDL data

The Pearson correlation coefficients in the ratio of synthetic measures in $2009 \mathrm{r}=0.441 / \mathrm{r} 2=0.194$ and in $2016 \mathrm{r}=0.519 / \mathrm{r} 2=0.269$. The obtained measures indicate a convergence process, a similar classification of poviat levels, and a small spatial diversification of operational effectiveness. Figure 1 indicates the bipolarity of changes, and the following poviats are distinctive: zamojski, białostocki, olsztyński, mielecki, kielecki, rzeszowski, stalowowolski.

Regression analysis allows creating a linear (or logarithmic) model, thanks to which it is possible to check how variables affect the dependent variable. When creating a regression model, it should be decided which variables will be an explanatory variable (a measure of financial situation), and which explanatory one. The regression model describing the dependence of variables takes the form:

FTOPSIS $=\mathrm{f}(\mathrm{F}, \mathrm{R}, \mathrm{G}, \mathrm{I}, \mathrm{Dp}, \mathrm{Dc}, \mathrm{Dn}, \mathrm{Dw}, \mathrm{Wm}, \mathrm{P}, \mathrm{O}$, $\operatorname{Pr}, \mathrm{S})$ :

$\mathrm{F}$ - a measure of the synthetic financial situation,

$\mathrm{R}$ - a measure of synthetic development potential,

$\mathrm{G}$ - a measure of synthetic economic potential,

I - a measure of the synthetic infrastructure potential,

$\mathrm{Dp}$ - Income from personal income tax,

Dc - Income from corporation tax,

Dn - Operating surplus,

Dw - Own income,

Wm - Property Expenses,

$\mathrm{P}$ - Total business entities,

$\mathrm{O}$ - Natural persons conducting the business activity,

Pr - Total employees,

$S$ - The unemployment rate.

The results of the analysis for $\mathrm{OE}$ allow stating that the presented regression model allows explaining $\mathrm{R} 2=0.59$ (estimation of the classic method of least squares) and 0.86 (logistic estimation). The high values of statistics F (10,250) 37.49 (7.254) and
236.09 respectively) and the corresponding probability level p $(<0.00001)$ confirm the statistical significance of the linear and logarithmic model. They also confirm that the parameters are significantly different from zero. The value of $\mathrm{t}$-Student's statistics at parameter $\mathrm{p}(<0.00001)$ means that all parameters are statistically significant.

R2 coefficient of determination measures how much of the overall volatility of a dependent variable is explained by linear regression. In our example, this value is R2 0.59 (estimation of the classic method of least squares) and 0.86 (logistic estimation). R2 equal to 1 is a perfect match, while $\mathrm{R} 2$ equal 0 means no relationship between variables. The corrected R2 ( 0.58 estimation of the classic least squares method, 0.86 logistic estimation) tells us how well our regression equation would fit into a different sample from the same population (Table 4 and 5 ).

Table 6 presents the correlation coefficients between the measure of financial situation and development and the economic and financial elements describing the poviats of Eastern Poland. The PIT and CIT incomes influenced the researched phenomena in the indicated period, the level of development in the case of financial situation and economic potential, economic entities and natural persons conducting economic activity in the case of development measure.

\section{Conclusion}

The activities of poviats have the character of a multicriteria category. They are affected by disability benefits, finances, economic and infrastructure potential, and natural resources. They form the basis for the operation of local government units and the condition for carrying out the tasks imposed on them. The balance of the region constituting the basis for the assessment of development is the sum of factors forming integrated order. The directions of the poviat's activity as a system of interdependent and 
Table 4

Estimation of the classic least squares method, used observations 1-261 (Variable dependent on the financial situation)

\begin{tabular}{|c|c|c|c|c|c|}
\hline & factor & stand. error & t-Student's & value $p$ & \\
\hline OE development & 0.513419 & 0.0609128 & 8.4288 & $<0.00001$ & *** \\
\hline OE infrastructure & -0.130396 & 0.0525967 & -2.4792 & 0.01383 & ** \\
\hline Total economic entities & 0.00402577 & 0.000841751 & 4.7826 & $<0.00001$ & *** \\
\hline $\begin{array}{l}\text { Natural persons conducting } \\
\text { economic activity }\end{array}$ & -0.0048145 & 0.00101445 & -4.7459 & $<0.00001$ & *** \\
\hline Income from corporation tax & 0.00360305 & 0.00100693 & 3.5782 & 0.00042 & *** \\
\hline Operating surplus & 0.000211474 & $7.43514 \mathrm{e}-05$ & 2.8443 & 0.00482 & *** \\
\hline Own income & 0.571685 & 0.0497548 & 11.4901 & $<0.00001$ & *** \\
\hline Property expenses & 0.0643387 & 0.0328986 & 1.9557 & 0.05162 & * \\
\hline Working total & -0.000221889 & $9.78966 \mathrm{e}-05$ & -2.2666 & 0.02427 & ** \\
\hline Unemployment rate & -0.00264038 & 0.00090117 & -2.9300 & 0.00370 & *** \\
\hline
\end{tabular}

\begin{tabular}{|l|c|l|l|c|}
\hline The arithmetic mean of the dependent variable & 0.341916 & & Standard deviation of a dependent variable & 0.063308 \\
\hline The sum of residual squares & 0.416822 & & Standard error of residues & 0.040832 \\
\hline Co determines R squared & 0.599995 & & Adjusted R-square & 0.583995 \\
\hline F $(10,250)$ & 37.49919 & & The p value for the F test & $2.64 \mathrm{e}-44$ \\
\hline Logarithm of credibility & 470.0269 & & Akaike inform. crit. & -918.0538 \\
\hline Schwarz-Bayesian crit. & -878.8441 & & Hannan-Quinn inform. crit. & -902.2928 \\
\hline
\end{tabular}

OE synthetic measure

Source: own study based on CSO BDL data

Table 5

Logistic estimation, used observations 1-261 (Variable dependent on the financial situation)

\begin{tabular}{|l|c|c|c|c|c|}
\hline & factor & stand. error & t-Student's & value $p$ & \\
\hline OE infrastructure & -0.981554 & 0.321612 & -3.0520 & 0.00251 & ${ }^{* * *}$ \\
\hline Natural persons conducting economic activity & -0.00600326 & 0.00208234 & -2.8829 & 0.00428 & ${ }^{* * *}$ \\
\hline Income from personal income tax & 0.00382073 & 0.000849536 & 4.4974 & 0.00001 & $*^{* * *}$ \\
\hline Income from corporation tax & 0.0275006 & 0.00637221 & 4.3157 & 0.00002 & $*^{* * *}$ \\
\hline Own income & 0.619357 & 0.313647 & 1.9747 & 0.04939 & ${ }^{* *}$ \\
\hline Working total & -0.00264057 & 0.000597913 & -4.4163 & 0.00001 & ${ }^{* * *}$ \\
\hline Unemployment rate & -0.032394 & 0.00482607 & -6.7123 & $<0.00001$ & $*^{* * *}$ \\
\hline
\end{tabular}

Basic statistics for transformed data:

\begin{tabular}{|l|c|l|c|}
\hline The sum of residual squares & 18.25171 & Standard error of residues & 0.268062 \\
\hline Co determines R squared & 0.866781 & Adjusted R-square & 0.863634 \\
\hline F $(7,254)$ & 236.0914 & The p value for the F test & $2.6 \mathrm{e}-107$ \\
\hline Logarithm of credibility & -23.17879 & Akaike inform. crit. & 60.35759 \\
\hline Schwarz-Bayesian crit. & 85.30923 & Hannan-Quinn inform. crit. & 70.38734 \\
\hline
\end{tabular}

Basic statistics for original data:

\begin{tabular}{|l|c|l|c|}
\hline The arithmetic mean of the dependent variable & 0.341916 & Standard deviation of a dependent variable & 0.063308 \\
\hline The sum of residual squares & 0.894773 & Standard error of residues & 0.059353 \\
\hline
\end{tabular}

Source: own study based on CSO BDL data

related financial, economic, social, infrastructural, and natural factors testify to the multidimensional character of the development process. They affect the economic situation of the local government, the conditions for the implementation of tasks.

Poviats are the centres of economic, social and cultural life. They focus on economic and social activities, in which there are disproportions. The synthetic measure enables the evaluation of a multidimensional phenomenon, as well as the linear ordering of the examined units. It can be a helpful tool for authorities to assess the accuracy of decisions taken in the past and the effectiveness of instruments used in the past. It gives a comparative image between objects subject to analysis; it allows indicating weaker and better areas of the unit's operation. 
Table 6

Correlation of the synthetic measure and its variable structure in 2009 and 2016

\begin{tabular}{|l|c|c|c|c|}
\hline \multirow{2}{*}{} & \multicolumn{2}{|c|}{2009} & \multicolumn{2}{|c|}{2016} \\
\cline { 2 - 5 } & OE financial situation & OE development potential & OE financial situation & OE development potential \\
\hline OE financial situation & 1,0000 & 0,4413 & 1,0000 & 0,5192 \\
\hline OE development potential & 0,4413 & 1,0000 & 0,5192 & 0,4058 \\
\hline OE economic potential & 0,2826 & 0,7295 & 0,3298 & 0,7622 \\
\hline Total business entities & 0,2029 & 0,6082 & 0,3901 & 0,5312 \\
\hline $\begin{array}{l}\text { Natural persons conducting } \\
\text { business activity }\end{array}$ & 0,2518 & 0,6092 & 0,6489 & 0,6138 \\
\hline Own income & 0,7763 & 0,3971 & 0,2405 \\
\hline $\begin{array}{l}\text { Income from personal } \\
\text { income tax }\end{array}$ & 0,4456 & 0,7649 & 0,3349 & 0,4243 \\
\hline Income from corporation tax & 0,4729 & 0,4027 & 0 \\
\hline
\end{tabular}

Linear correlation coefficients for observations from sample 1-87; Critical value (with a two-sided $5 \%$ critical area) $=0.2108$ for $\mathrm{n}=87$

Source: own study based on CSO BDL data

The income situation and financial independence of communes were related to the economic situation of the region. The financial situation of the poviat is the source of information on the potential of the individual's economic development. It affects the quality of life of residents. Information about the state of finances of cities with poviat rights forms the basis for a comprehensive assessment of the activities of the local government, and the expenses implemented indicate the development opportunities of these units.

The situation of the surveyed units varied. The ranking of cities in the ranking did not change substantially in the subsequent years. It was confirmed that financial resources are the basis for the operation of individuals and a condition for carrying out the tasks imposed on them, determine development, and reflect the potential for economic development.

\section{References:}

Bieniasz, A., Gołaś, Z., Łuczak, A. (2013). Zastosowanie metody TOPSIS do oceny kondycji finansowej gmin w Polsce w 2010 roku, Zeszyty Teoretyczne Rachunkowości, t. 70(126), SKwP, Warszawa, pp. $25-42$.

Churski, P., i inni (2013). Czynniki rozwoju obszarów wzrostu i obszarów stagnacji gospodarczej w Polsce, Uniwersytet im. Adama Mickiewicza, Poznań.

Domański, B. (2010). Should we fight local and regional disparities in economic development in Poland? Studia Regionalia KPZK PAN 27(1), pp. 132-141.

Dziekański, P. (2014). Koncepcja wskaźnika syntetycznego do oceny sytuacji finansowej powiatów, Research Papers of Wroctaw University of Economics, nr 329.

Dziekański, P. (2016). Spatial changes and assessment of the financial condition of local government units in the context of the income structure. In: Formankova S., International Conference on Management (ICoM), Trends of Management in the Contemporary Society (Peer-Reviewed Conference Proceedings), Brno, Publisher: Mendelova univerzita v Brně.

Dziekański, P. (2018). Ocena efektywności funkcjonowania gmin województwa świętokrzyskiego w świetle ekonomii instytucjonalnej (analiza wielowymiarowa), Uniwersytet Jana Kochanowskiego, Kielce.

Dziekański, P. (2018a). Territorialisation Of Spatial Disproportions Of Infrastructure And Development Of Rural Areas Of The Swietokrzyskie Voivodship. In: Proceedings of the 2018 International Conference "Economic Science For Rural Development" No 47 Jelgava, LLU ESAF, 911 May 2018, pp. 73-80.

Dziekański, P., Wyszkowski, A. (2018). Ocena przestrzennego zróżnicowania sytuacji finansowej gmin województwa świętokrzyskiego z wykorzystaniem miary syntetycznej, Optimum. Economic Studies NR 1(91), pp. 219-238.

Głowicka-Wołoszyn, R., Satoła, Ł. (2018). Financial self-sufficiency of rural communes in Poland, International Scientific Days 2018 ISD/MVD, Nitra, p. s. 1493-1495.

Gonet, W. (2013). Naprawa finansów jednostki samorządu terytorialnego, Difin, Warszawa, p. 125.

Gorzelak, G. (2003). Bieda i zamożność regionów - założenia, hipotezy przykłady. Uniwersytet Warszawski, Centrum Studiów Regionalnych i Lokalnych, Studia Regionalne i Lokalne nr 1(11), pp. 37-58.

Governmental Accounting Standards Board (GASB) (1987). USA. As: Stanny, M., Strzelczyk, W. (2018). Kondycja finansowa samorządów terytorialnych a rozwój społeczno-gospodarczy obszarów wiejskich, ujęcie przestrzenne, IRWIR PAN, Warszawa.

Hok, B. (2016). Wybrane czynniki finansowe do oceny zamożności jednostek samorządu terytorialnego na przykładzie gmin wiejskich i miejsko-wiejskich województwa zachodniopomorskiego, Zeszyty Naukowe Politechnika Koszalińska, Wydział Nauk Ekonomicznych, Nr 20, T. 1. 
Kukuła, K. (2000). Metoda unitaryzacji zerowanej, PWN, Warszawa.

Kukuła, K. (2014). Regionalne zróżnicowanie stopnia zanieczyszczenia środowiska w Polsce a gospodarka odpadami. In: Piekutowska A., Rolnik-Sadowska E., (red.), Wybrane problemy zarządzania rozwojem regionalnym, Przedsiębiorczość i Zarządzania, Wydawnictwo SAN, t. XV, 8, część I, pp. 183-198.

Łuczak, A., Wysocki, F. (2012). Zastosowanie uogólnionej miary odległości GDM oraz metody TOPSIS do oceny poziomu rozwoju społeczno-gospodarczego powiatów województwa wielkopolskiego, Przegląd Statystyczny, 59, numer specjalny 2, pp. 298-311.

Malina, A. (2004). Wielowymiarowa analiza przestrzennego zróżnicowania struktury gospodarki Polski według województw, Kraków: Wyd. Akademii Ekonomicznej w Krakowie.

Marcysiak, T., Prus, P. (2017). Life strategies of rural inhabitants of unfixed economic function. Proceedings of the 26th International Scientific Conference Agrarian Perspectives XXVI Competitiveness of European Agriculture and Food Sectors, Czech University of Life Sciences Prague, Faculty of Economics and Management.

Michoń, D. (2017). Zróżnicowanie rozwoju społeczno-gospodarczego województw ze względu na realizację celów polityki spójności, Wiadomości statystyczne, Rok LXII 12(679), pp. 80-94.

Olejniczak-Szałowska, E. (2000). Zadania własne i zlecone samorządu terytorialnego, Samorząd Terytorialny, Nr 12, p. 10.

Ossowska, L. Ziemińska, A. (2010). Kondycja finansowa gmin wiejskich i miejsko-wiejskich województwa pomorskiego, Journal of Agribusiness and Rural Development, nr 4(18), pp. 73-74.

Program Operacyiny Polska Wschodnia 2014-2020. Retrieved from: https://www.polskawschodnia.gov.pl/ media/1278/.Program_Polska_Wschodnia_2014_2020.pdf

Prus, P., Drzazdzyńska, K. (2017). Farmers' assessment of training services and the impact of agricultural advisory on selected developmental factors affecting farming. In: Proceedings of the 2017 International Conference ECONOMIC SCIENCE FOR RURAL DEVELOPMENT, No 44, Jelgava, LLU ESAF, pp. 27-28.

Satoła, Ł., Standar, A., Kozera, A. (2019). Financial Autonomy of Local Government Units: Evidence from Polish Rural Municipalities, Lex localis - Journal of Local Self-Government, Vol. 17, No. 2, p. 330.

Stanny, M. (2013). Przestrzenne zróżnicowanie rozwoju obszarów wiejskich w Polsce, IRWiR PAN, Warszawa.

Strategia rozwoju Polski Wschodniej, 2020, Synteza. Retrieved from: https://archiwum.miir.gov.pl/media/3373/ Strategia_rozwoju_Polski_Wschodniej_2020_synteza.pdf

Ślusarz, G. (2005). Studium społeczno-ekonomicznych uwarunkowań rozwoju obszarów wiejskich w świetle zagrożenia marginalizacją na przykładzie województwa podkarpackiego. Wydawnictwo Uniwersytetu Rzeszowskiego, Rzeszów.

Wysocki, F. (2010). Metody taksonomiczne w rozpoznawaniu typów ekonomicznych rolnictwa i obszarów wiejskich. Uniwersytet Przyrodniczy w Poznaniu, Poznań.

Wysocki, F., Lira, J. (2005). Statystyka opisowa. Poznań: Wydawnictwo Uniwersytetu Przyrodniczego w Poznaniu. Zalewski, W. (2012). Zastosowanie metody TOPSIS do oceny kondycji finansowej spółek dystrybucyjnych energii elektrycznej Ekonomia i Zarządzanie, 4. 